\title{
PENGGUNAAN METODE MENGAJAR DI PAUD DALAM RANGKA MENUMBUHKAN MINAT BELAJAR ANAK
}

\author{
Oleh \\ I KETUT TANU \\ Institut Hindu Dharma Negeri Denpasar \\ ketuttanu@gamil.com
}

\begin{abstract}
ABSTRAK
Tidak ada metode mengajar yang tepat diterapkan pada setiap pembelajaran akibatnya, metode pembelajaran anak PAUD sebagai metode pembelajaran PAUD adalah yang Efektif dan Menyenangkan. Sebab semua bisa mengajar namun belum tentu bisa mengajar di TK atau PAUD. Mengajar PAUD berarti mengajar anak yang sedang ada di masa usia keemasannya (golden age).Sebuah masa dimana potensi anak sedang berkembang dan saat yang tepat untuk membuatnya menjadi seorang pembelajar yang mandiri dan haus pengetahuan. Bagi anak, bermain merupakan suatu kegiatan yang sifatnya melekat langsung pada kodrat dan kebutuhan perkembangan anak.

Pemahaman tentang pembelajaran anak usia dini dengan bermain, saat ini diharapkan sudah lebih dipahami para pengelola, pendidik atau pemerhati. Disamping itu lingkungan kondusif juga diperlukan bagi anak dengan pengertian lingkungan kondusif adalah lingkungan yg menstimulasi agar anak bisa dan mampu menjadi pembelajar yg mandiri.

Selain melalui bermain, memperhatikan cara anak berpikir, cara anak bermain, dan cara anak berbicara adalah keseharian guru PAUD.

Oleh karena itu penguasaan metode-metode pembelajaran anak usia dini merupakan salah satu kompetensi yang harus dimiliki guru/tutor agar proses pembelajaran tersebut dapat mendorong perkembangan anak, baik perkembangan intelektual, fisik maupun emosionalnya. Dengan menguasai metode pembelajaran, selain tentunya kemampuan lainnya, seorang guru/ tutor dapat mengelola proses pembelajaran sesuai dengan tujuan yang hendap dicapainya, yaitu kemampuan-kemampuan yang diharapkan dimiliki oleh anak
\end{abstract}

Kata kunci; Penggunaan, Metode pembelajaran, PAUD.

\section{PENDAHULUAN}

Metode pembelajaran untuk anak usia dini hendaknya menantang dan menyenangkan, melibatkan unsur bermain, bergerak bernyanyi dan belajar. Beberapa metode yang sering digunakan untuk proses belajar mengajar. Metode dasar yang bisa digunakan oleh pendidik hendaknya punya keinginan menyampaikan pengetahuan kepada anak didik.Sehingga menurut para ahli secara epistemologi: Metode belajar mengajar dapat diartikan sebagai cara-cara yang dilakukan untuk menyampaikan atau menanamkan pengetahuan kepada anak didik melalui sebuah kegiatan belajar mengajar, baik di sekolah, rumah, kampus, dll.

Metode adalah cara yang fungsinya sebagai alat untuk mencapai tujuan. Makin baik metode itu, makin efektif pula pencapaian tujuan. Dengan demikian tujuan merupakan faktor utama dalam menetapkan baik tidaknya penggunaan suatu metode.Metode mengajar, selain faktor tujuan, murid, situasi, fasilitas dan faktor guru turut menentukan efektif tidaknya penggunaan suatu metode. Karenanya metode mengajar itu banyak sekali dan sulit menggolong-golongkannya. Lebih sulit lagi menetapkan metode mana yang memiliki efektifitas paling tinggi. Sebab metode yang "kurang baik" di tangan seorang guru dapat menjadi metode yang "baik sekali" di tangan guru yang lain dan metode yang baik akan gagal 
di tangan guru yang tidak menguasai teknik pelaksanaannya. Namun demikian, ada sifatsifat umum yang terdapat pada metode yang satu tidak terdapat pada metode yang lain. Dengan mencari ciri-ciri umum itu, menjadi mungkinlah untuk mengenali berbagai macam metode yang lazim dan praktis untuk dilaksanakan dalam proses belajar mengajar. Belajar mengajar merupakan kegiatan yang kompleks. Mengingat kegiatan belajar mengajar merupakan kegiatan yang kompleks, maka tidak mungkin menunjukan dan menyimpulkan bahwa suatu metode belajar mengajar tertentu lebih unggul dari pada metode belajar mengajar yang lainnya dalam usaha mencapai semua pelajaran, dalam situasi dan kondisi, dan untuk selamanya. Untuk itu berikut ini akan dibahas beberapa metode yang dimungkinkan dapat digunakan dalam pembelajaran pendidikan seperti metode ceramah, metode diskusi, metode kelompok dan metode campuran.

Untuk mencapai hal itu, maka guru harus dapat memilih dan mengembangkan metode mengajar yang tepat, efisien dan efektif sesuai dengan materi yang diajarkan. Dengan pemilihan metode yang tepat, maka akan mempengaruhi belajar siswa dengan baik sehingga siswa benar-benar memahami materi yang akan diberikan. Metode pembelajaran PAUD adalah cara yang digunakan pendidik dalam melakukan kegiatan pembelajaran kepada anak untuk mencapai kompetensi tertentu. Metode pembelajaran dirancang dalam kegiatan bermain yang bermakna dan menyenangkan bagi anak didik.

\section{PEMBAHASAN}

\subsection{Pengertian Metode Mengajar}

Metode berasal dari dua kata, yaitu meta dan hodos. Meta berarti 'melalui' dan hodos berarti 'jalan' atau 'jalan'. Dengan demikian metode adalah dapat berarti cara atau jalan yang harus dilalui untuk mencapai suatu tujuan. Ada juga yang mengartikan bahwa metode adalah suatu sarana untuk menemukan, menguji, dan menyusun data yang diperlukan bagi pengembangan disiplin tersebut. Singkatnya metode adalah jalan untuk mencapai tujuan. Adapun kata 'metodologi' berasal dari kata 'metoda' dan 'logi'. Logi berasal dari bahasa Yunani logos yang berarti akal atau ilmu. Jadi metodologi artinya ilmu tentang jalan atau cara yang harus dilalui untuk mencapai suatu tujuan. Sebagai suatu ilmu, metodologi merupakan bagian dari perangkat disiplin keilmuan yang menjadi induknya. Hampir semua ilmu pengetahuan mempunyai metodologi tersendiri.

Oleh karena itu ilmu pendidikan sebagai salah satu disiplin ilmu juga memiliki metodologi yaitu metodologi pendidikan. Dengan demikian yang dimaksud dengan metode pengajaran yaitu suatu ilmu pengetahuan tentang motode yang dipergunakandalam pekerjaan mendidik. Atau bisa juga yang dimaksud metode mengajar adalah suatu pengetahuan tentang cara-cara mengajar yang di pergunakan oleh seorang guru atau instruktur. Metode mengajar yang digunakan untuk menyampaikan informasi berbeda dengan cara yang ditempuh untuk memantapkan siswa dalam menguasai pengetahuan keterampilan, dan sikap (kognitif, efektif). Khusus metode mengajar di dalam kelas, efektivitas suatu metode dipengaruhi oleh factor tujuan, factor siswa, factor situasi, dan factor guru itu.

Untuk lebih jelasnya berikut ini definisi dan pengertian metode pembelajaran menurut beberapa ahli diantaranya :

\section{Abdurrahman Ginting}

Metode pembelajaran dapat diartikan cara atau pola yang khas dalam memanfaatkan berbagai prinsip dasar pendidikan serta berbagai teknik dan sumberdaya terkait lainnya agar terjadi proses pemblajaran pada diri pembelajar.

\section{Ahmadi (1997: 52)}

Suatu pengetahuan tentang cara cara mengajar yang dipergunakan oleh guru atau instruktur.

\section{Hasby Ashydiqih}

Metode Pembelajaran berpendapat bahwa, metode pembelajaran adalah seperangkat cara yang dilakukan untuk mencapai tujuan tertentu dalam proses pembelajaran. 
Geriach Ely dalam bukunya Strategi Dalam Proses Belajar

Metode pembelajaran adalah cara-cara yang dipilih untuk menyampaikan pelajaran dalam lingkungan pengajaran tertentu, yang meliputi sifat, lingkup dan urutan kegiatan yang dapat memberikan pengalaman belajar kepada siswa.

\section{Nana Sudjana (2005: 76)}

Metode pembelajaran adalah, "Metode pembelajaran ialah cara yang dipergunakan guru dalam mengadakan hubungan dengan siswa pada saat berlangsungnya pengajaran"

\section{Sobri Sutikno (2009: 88)}

Metode pembelajaran adalah cara-cara menyajikan materi pelajaran yang dilakukan oleh pendidik agar terjadi proses pembelajaran pada diri siswa dalam upaya untuk mencapai tujuan.

\section{Gerlach dan Elly ( 80:14)}

Metode pembelajaran dapat diartikan sebagai rencana yang sistematis untuk menyampaikan informasi.

\section{Salamun (dalam Sudrajat, 2009:7)}

Metode pembelajaran ialah sebuah caracara yang berbeda untuk mencapai hasil pembelajaran yang berbeda dibawah kondisi yang berbeda.

Demikianlah tentang pengertian metode pembelajaran menurut para ahli dan diharapkan dapat menambah pengetahuan di dalam memahami definisi metode pembelajaran yang baik dan benar.

\subsection{Prinsip - Prinsip Pengguanaan Metode Mengajar di PAUD}

Pendidik harus mampu memilih metode yang tepat sesuai dengan tujuan dan keadaan pembelajaran. SababKesalahan dalam memilih metode dalam mengajar berarti telah merancang kegagalan dalam pembelajaran. Sebagai petunjuk dalam memilih metode yang tepat ada beberapa prinsip dalam menentukan metode pembelajaran, diantaranya: Berorientasi pada tujuan pembelajaran dan merupakan komponen yang utama dalam sistem pembelajaran. Sebab segala aktivitas pendidik dan peserta didik mestilah diupayakan untuk mencapai tujuan yang telah ditetapkan. Ini sangat penting sebab mengajar adalah proses yang bertujuan. Oleh karena itu keberhasilan suatu metode pembelajaran dapat ditentukan dari keberhasilan peserta didik mencapai tujuan pembelajaran. Tujuan pembelajaran dapat menentukan suatu metode yang harus digunakan akan tetapi hal ini sering dilupakannya.

Pendidik yang senang berceramah hampir setiap tujuan menggunakan metode ceramah seakan-akan semuanya dapat dicapai melalui metode ceramah. Berorientasi pada aktivitas peserta didik, belajar bukan sebatas aktifitas menghafal sejumlah informasi. Belajar adalah berbuat yakni memperoleh pengalaman tertentu sesuai dengan tujuan yang diharapkan. Karena itu metode pembelajaran harus dapat mendorong aktifitas peserta didik. Aktifitas tidak dimaksudkan terbatas pada aktivitas fisik akan tetapi meliputi aktivitasa yang bersifat mental. Banyak pendidik yang terkecoh oleh sikap peserta didik yang pura-pura aktif padahal sebenarnya tidak. Berorientasi pada individualitas, mengajar adalah usaha mengembangkan setiap individu peserta didik. Walaupun guru mengajar sekelompok peserta didik namun pada hakikatnya yang ingin dicapai adalah perubahan perilaku setiap siswa. Kalau melihat dari jumlah peserta didik sebaiknya standar keberhasilan guru ditentukan setinggi-tingginya. Berorientasi pada integritas, mengajar harus dipandang sebagai usaha mengembangkan seluruh pribadi siswa. Mengajar bukan hanya mengembangkan kemampuan kognitif saja akan tetapi meliputi pengembangan aspek afektif dan psikomotorik.

Oleh karena itu pembelajaran harus diarahkan untuk mengembangkan seluruh aspek kepribadian peserta didik secara teritergrasi. Penggunaan metode diskusi misalnya maka seorang pendidik harus dapat merancang strategi pelaksanaan diskusi tidak hanya terbatas pada pengembangan aspek intelektual tetapi harus mendorong peserta didik agar bisa berkembang secara 
keseluruhan, yaitu agar peserta didik dapat menghargai pendapat orang lain, seperti lebih berani berpendapat dan bersikap jujur, tenggang rasa dan lain sebagainya.

Adapun faktor- faktor yang mempengaruhi proses belajar dikaji dari penggunaan metoda adalah sebagai berikut:

1. Faktor raw input (yakni factor murid / anak itu sendiri ) dimana tiap anak memiliki kondisi yang berbeda- beda dalam kondisi fisiologi dan kondisi psikologis

2. Faktor environmental input (yakni factor lingkungan), baik itu lingkungan alami maupun lingkungan social

3. Faktor instrumental input, yang didalamnya antara lain terdiri dari:

a. Kurikulum

b. Program atau bahan pengajaran

c. Sarana dan fasilitas

d. Guru( tenaga Pengajar)

Adapun uraian mengenai faktor-faktor yang mempengaruhi proses belajar adalah:

1. Faktor dari luar terdiri dari:

a. faktor environ mental input ( Lingkungan) Kondisi lingkungan juga dipengaruhi proses dan hasil belajar. Lingkungan fisik/ alami termasuk didalamnya adalah seperti keadaan suhu, kelembaban, kepengapan udara, dan sebagainya, lingkungan social, baik yang berwujud manusia maupun hal- hal lainnya, juga dapat mempengaruhi proses dan hasil belajar.

b. Faktor- factor Environ mental Faktor- factor environ mental adalah factor yang keberadaan dan penggunaannya dirancangkan sesuuai hasil belajar yang diharapkan.

2. Faktor dari dalam yaitu kondisi individu atau anak yang belajar itu sendiri, factor individu dapat dibagi menjadi dua bagian:

a. kondisi fisiologis anak

Secara umum kondisi fisiologis, seperti kesehatan yang prima, tidak dalam keadaan capek, tidak dalam keadaan cacat jasmani, seperti kakinya atau tangannya (karena ini akan menggangggu kondisi fisiologis) dan sebagainya, akan sanagat membantu dalam proses dan hasil belajar. Karena pentingnya penglihatan dan pendengaran maka dalam lingkungan pendidikan formal, orang melakukan berbagai penelitian untuk menemukan bentuk dan cara menggunakan alat peraga yang dapat dilihat sekaligus didengar ( audio visual aids)

b. kondisi psikologis

Sebagaimana diuraikan terdahulu mengenai dasar-dasar psikologis belajar dimana sikap manusia atau anak didik pada dasarnya memiliki kondisi psikologis yang berbedabeda (terutama dalam hal kadar bukan dalam hal jenis), maka sudah tentu ( perbedaan-perbedaan itu sangat mempengaruhi proses dan hasil belajar. Beberapa factor psikologis yang dianggap utama dalam hal mempengaruhi proses dan hasil belajar:
a. minat
b. kecerdasan
c. motivasi
d. kemampuan-kemampuan kognitif

Sehingga ada beberapa prinsif yang perlu diperhatikan dalam penggunaan metode mengajar diantaranya :

1. Metode mengajar harus memungkinkan dapat mengakibatkan rasa ingin tahu siswa lebih jauh terhadap materi pelajaran (curiosity).

2. Metode mengajar harus harus memungkinkan dapat memberikan peluang untuk berekspresi yang kreatif dalam aspek seni.

3. Metode mengajar harus memungkinkan siswa belajar melalui pemecahan masalah.

4. Metode mengajar harus memungkinkan siswa untuk selalu ingin menguji kebenaran sesuatu (sikap skeptis).

5. Metode mengajar harus memungkinkan 
siswa untuk melakukan penemuan (berinkuiri) terhadap sesuatu topik permasalahan.

6. Metode mengajar harus memungkinkan siswa mampu menyimak.

7. Metode mengajar harus memungkinkan siswa untuk belajar mandiri (independent study).

8. Metode mengajar harus memungkinkan siswa untuk belajar secara bekerja sama (cooperative learning).

9. Metode mengajar harus memungkinkan siswa untuk belajar mandiri untuk lebih termotivasi dalam belajarnya.

\subsection{Metode Yang Dapat Dipergunakan Di PAUD}

Suatu metode pembelajaran dikatakan efektif dan efisien dalam membelajarkan apabila siswa dapat menguasai materi pelajaran. Atau dengan kata lain, seberapa besar penyerapan informasi belajar oleh siswa melalui metode pembelajaran yang digunakan. Belajar mengajar merupakan suatu proses yang rumit, karena bukan sekedar menyerap informasi dari guru, melainkan melibatkan berbagai kegiatan maupun tindakan yang harus dilakukan terutama bila menginginkan hasil belajar yang baik.

Pendidik adalah orang dewasa dengan segala kemampuan yang dimilikinya untuk dapat mengubah psikis dan pola pikir siswa dari tidak tahu menjadi tahu serta mendewasakannya. Salah satu hal yang harus dilakukan oleh guru adalah dengan mengajar di kelas. Salah satu yang paling penting adalah performance guru di kelas. Bagaimana seorang pendidik dapat menguasai keadaan kelas sehingga tercipta suasana belajar yang menyenangkan.

Tiap-tiap kelas bisa kemungkinan menggunakan metode pembelajaran yang berbeda dengan kelas lain. Untuk itu msaka orang pendidik harus mampu menerapkan berbagai metode pembelajaran. Salah satu cara belajar mengajar yang menekankan berbagai kegiatan dan tindakan adalah dengan menggunakan suatu metode tertentu dalam belajar mengajar. Hal ini dikarenakan metode dalam belajar mengajar pada hakekatnya merupakan suatu upaya dalam mengembangkan dan mengoptimalkan keaktifan belajar mengajar yang dilakukan oleh siswa dan pendidik.

Kualitas belajar mengajar, sebenarnya tidak terlepas dari metode yang digunakan dalam proses belajar mengajar, karena berhasil tidaknya tujuan yang akan dicapai dipengaruhi oleh efektif dan tidaknya proses belajar mengajar yang dialami serta tergantung juga dari dalam diri siswa itu sendiri. Kenyataan di lapangan menunjukkan bahwa siswa di sekolah kita pada umumnya heterogen (mempunyai kemampuan yang bervariasi), sementara sebagai pendidik sering menganggap semua siswa di suatu kelas memliki tingkat kemampuan yang relatif sama, sehingga kurang memperhatikan adanya perbedaan-perbedaan tersebut.

Mengenai jenis-jenis metode yang sesuai dengan kondisi kelas, guru akan lebih faham tentang metode yang paling tepat untuk diterapkan di kelasnya, karena hampir setiap hari menghadapi siswa dengan berbagai masalahnya. Ada banyak metode pembelajaran yang dapat dijadikan salah satu alternatif yaitu metode diskusi, tanya jawab, metode inguary, demostrasi / praktikum dan sebagainya.

Ada beberapa metode pembelajaran yang dapat dipergunakan di PAUD di antaranya adalah sebagai berikut:

\section{a. Bercerita}

Bercerita adalah cara bertutur dan menyampaikan cerita secara lisan. Cerita harus diberikan secara menarik. Anak diberi kesempatan untuk bertanya dan memberikan tanggapan. Pendidik dapat menggunakan buku sebagai alat bantuuntuk bercerita.

b. Demonstrasi

Demonstrasi digunakan untuk menunjukkan atau memeragakan cara untuk membuat atau melakukan sesuatu.

c. Sosio-drama/bermain peran

Sosio-drama atau bermain peran dilakukan untuk mengembangkan 
daya khayal/imajinasi, kemampuan berekspresi, dan kreativitas anak yang diinspirasi dari tokoh-tokoh atau bendabenda yang ada dalam cerita.

\section{d. Karyawisata}

Karyawisata adalah kunjungan secara langsung ke objek-objek di lingkungan kehidupan anak yang sesuai dengan tema yang sedang dibahas.

\section{PENUTUP}

\subsection{Kesimpulan}

Berdasarkan uraian pada pembahasan maka beikut ini dapat disimpulkan hal-hal sebagai berikut:

1. Metode adalah jalan untuk mencapai tujuan. Adapun kata 'metodologi' berasal dari kata 'metoda' dan 'logi'. Logi berasal dari bahasa Yunani logos yang berarti akal atau ilmu

2. Factor environ mental input (Lingkungan) Kondisi lingkungan juga dipengaruhi proses dan hasil belajar. Lingkungan fisik/ alami termasuk didalamnya adalah seperti keadaan suhu, kelembaban, kepengapan udara, dan sebagainya, lingkungan social, baik yang berwujud manusia maupun halhal lainnya, juga dapat mempengaruhi proses dan hasil belajar.

3. Faktor dari dalam Factor dari dalam adalah kondisi individu atau anak yang belajar itu sendiri, factor individu dapat dibagi menjadi dua bagian : didengar ( audio visual aids)

4. Ada beberapa metode pembelajaran yang dapat dipergunakan dik PAUD tentang metode pembelajara

\subsection{Saran}

1 .Metode pembelajaran di PAUD hendaknya mengacu pada UU pendidikan.

2. Metode pembelajaran di PAUD adalah belajar sambil bermain

\section{DAFTAR PUSTAKA}

Andriano,dkk 2006. Melejitkan Potensi Anak. MLC Bandung

Anwar dkk,2013. Konsep Dasar Ilmu Pendidikan Alfabeta Bandung

Ahmadi Abu H. Drs, (2005) Strategi Belajar Mengajar, Bandung: Armico.

Depag RI, Stategi Belajar Mengajar, Dirjen Bimbingan Islam, Jakarta.

Mansyur. H. Drs, (1991), Strategi Belajar Mengajar, Jakarta: Universitas Terbuka

Sanjaya Wina, Dr. (2006) Strategi Pembelajaran, Jakarta

Sudirman, N, Drs, dkk, Ilmu Pendidikan, Rosdakarya, Bandung.

Nasution, S, (1989), Kurikulum dan Pengajaran, Bandung: Bina Aksara.

Tata raharjo, dkk. Pendidikan Populer Membangun Kesadaran kritis. Insit pres Jgjakarta.

Zakiah Daradjat, Metode Khusus Pengajaran Agama Islam,( Jakarta: Bumi Aksara,1995), hal. 298 